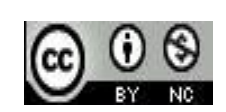

Jurnal Pendidikan Bahasa dan Sastra Indonesia is licensed under

A Creative Commons Attribution-Non Commercial 4.0 International Licens

\title{
Representasi Ketidakadilan pada Kumpulan Puisi Nyanyian Akar Rumput Karya Wiji Thukul
}

\author{
Fetti Astrini Rishanjani ${ }^{1)}$, Zainal Rafli ${ }^{2)}$, Zuriyati $^{3)}$ \\ ${ }^{1)}$ Universitas Negeri Jakarta \\ E-mail: fettiastrini_pb15s2@mahasiswa.unj.ac.id \\ ${ }^{2)}$ Universitas Negeri Jakarta \\ E-mail: zainal.rafli@unj.ac.id \\ ${ }^{3)}$ Universitas Negeri Jakarta \\ E-mai: zuriyati@unj.ac.id
}

\begin{abstract}
Abstrak: Penelitian ini bertujuan untuk mengkaji secara mendalam mengenai representasi ketidakadilan yang terdapat di dalam kumpulan puisi Nyanyian Akar Rumput karya Wiji Thukul serta implikasinya dalam pembelajaran bahasa Indonesia. Penelitian ini merupakan penelitian kualitatif dengan menggunakan metode analisis deskriptif. Hasil penelitian menyimpulkan puisi yang dianalisis mempresentasikan adanya tindak ketidakadilan kreatif. Hasil penelitian menunjukkan: (1)Representasi ketidakadilan kreatif ditemukan pada puisi berjudul "Peringatan" yang mengungkapkan tentang ketidakbebasan rakyat dalam menyuarakan kritik untuk memperjuangkan hak-haknya sebagai warga negara; (2) Implikasi representasi ketidakadilan pada puisi dalam pembelajaran bahasa Indonesia dapat dimanfaatkan oleh guru dan siswa sebagai bahan pembelajaran sastra.
\end{abstract}

Kata Kunci: representasi ketidakadilan; puisi; literasi kritis

\section{PENDAHULUAN}

Keberadaan puisi di tengah masyarakat urban menimbulkan berbagai reaksi dan tanggapan. Hal tersebut wajar adanya karena sebuah karya akan dikenal apabila penilaian berupa pujian dan kritikan terus bermunculan sebagai bentuk pengapresiasian sebuah karya sastra. Dalam kesusastraan, apresiasi sastra diperlukan agar pengarang dapat memahami segala reaksi pembaca terhadap karya yang mereka ciptakan yang kemudian dijadikan aset untuk merumuskan karya-karya berikutnya. Pengapresiasian ini berkaitan dengan bentuk karya sastra sebagai cerminan kehidupan pengarang yang biasanya berisi pengalaman hidup atau pandangan hidup yang di dalamnya terkandung pesan dan nilai-nilai kehidupan yang dapat dipelajari. Karya sastra khususnya puisi sering dikenal dengan "dokumen sosial" yaitu sebagai rekam jejak yang mencatat realitas keadaan sosial budaya pada masa karya itu diciptakan. Berkenaan dengan sesuatu yang dapat dijadikan pembelajaran, puisi pun sejak lama telah dihadirkan dalam kegiatan pembelajaran di sekolah salah satunya melalui mata pelajaran Bahasa Indonesia.
Dalam Kurikulum 2013, materi dalam pelajaran Bahasa Indonesia lebih mengutamakan muatan kebahasaan dibandingkan dengan kesusastraan (Pr.M.Basir, 2017:233). Hal ini dapat dilihat dari materi pelajaran yang mayoritas berbasis teks-teks kebahasaan sehingga eksistensi sastra khususnya puisi kurang terpampang jelas dalam pembelajaran bahasa Indonesia. Terkait minimnya contohcontoh teks sastra dalam buku pelajaran memicu keterbatasan pendidik dalam memberikan bahan pembelajaran untuk peserta didik. Selain itu, pembelajaran puisi di sekolah cenderung mengajarkan pengetahuan tentang teori puisi bukan keterampilan berpuisi (Indriati \& Haryadi, 2014:157).

Berdasarkan indikator pembelajaran sastra dalam silabus pelajaran Bahasa Indonesia, peserta didik harus memiliki kemampuan untuk mengapresiasi sebuah karya sastra yaitu puisi. Peserta didik dituntut untuk menggauli puisi dengan sungguh-sungguh dan mampu memahami unsur-unsur yang terkandung dalam puisi sehingga dapat menumbuhkan pengertian, penghargaan, dan kepekaan pemikiran serta perasaan terhadap karya sastra itu sendiri.

Puisi diciptakan berdasarkan pengalaman hidup dan kehidupan pengarang. Oleh sebab itu, puisi diciptakan 
berdasarkan fakta-fakta yang ada atau realitas sosial yang ada pada saat puisi tersebut diciptakan. Sehubungan dengan ini, karya sastra tidak secara keseluruhan merupakan imajinasi karena karya sastra dikontruksi atas dasar kenyataan (Ratna, 2012:307). Oleh karena itu, diperlukanlah alternatif tema puisi yang sarat makna dalam pembelajaran puisi di sekolah terutama tema puisi yang berkaitan dengan kehidupan sosial dan isu-isu sosial yang terjadi di masyarakat agar wawasan peserta didik menjadi lebih luas dan kepedulian terhadap masalah-masalah sosial pun dapat terasah. Analisis puisi yang dapat digunakan untuk menungkap hubungan antara teks puisi dengan kenyataan sosial adalah Analisis Literasi Kritis (ALK). Konsep literasi kritis ini diadopsi dari analisis wacana kritis yang dikemukakan oleh Norman Fairclough (dalam Priyatni, 2010:29). Eriyanto dalam Sjarif \& Prasetio (2017:3376) mengungkapkan bahwa wacana dipakai untuk menguak kuasa yang ada dalam setiap proses bahasa, batasan-batasan yang diperkenankan menjadi wacana, perspektif yang harus dipakai, dan topik yang dibicarakan. Dengan demikian, wacana melihat bahasa selalu terlibat dalam hubungan kekuasaan, terutama dalam pembentukan subjek, dan berbagai tindakan representasi yang terdapat dalam masyarakat. Dengan ALK pula dapat diungkap maksud tersembunyi di balik teks. Konsep dasar literasi kritis berinduk pada teori kritis yang meyakini bahwa ada kepentingan tertentu (ideologi) di balik sebuah teks. Literasi kritis meyakini dalam menginterpretasikan teks sastra tidak sekadar memahami teks sastra sebagai perlambangan atau pengkodean kata-kata dalam teks. Akan tetapi, dalam memahami teks sastra harus mengaitkan bahasa sebagai kontruk sosial (Priyatni, 2010:24).

Penelitian terkait Analisis Literasi Kritis dilakukan oleh Basuki Priatno seorang mahasiswa Universitas Pendidikan Indonesia pada tahun 2013 dengan judul tesisnya yaitu Analisis Literasi Kritis Puisi-Puisi Taufiq Ismail Dalam Kumpulan Puisi Malu (Aku) Jadi Orang Indonesia Yang Merepresentasikan Kekuasaan dan Pemanfaatannya Dalam Pembelajaran Puisi di SMA. Hasil penelitian menyimpulkan bahwa puisi-puisi yang dianalisis mempresentasikan kekuasaan; subordinasi, diskriminasi, dan represi. Representasi kekuasaan itu didukung dengan penggunaan diksi, pengimajian, majas, tema, dan aspek historis puisi. Uji coba yang dilakukan dalam pembelajaran puisi di SMA Negeri 1 Damangan, Purwakarta menunjukkan hasil yang cukup baik. Tujuh puluh dua persen siswa memperoleh nilai mencapai KKM, $28 \%$ siswa memperoleh nilai di bawah KKM. Nilai rata-rata yang diperoleh siswa sebesar 71 melebihi nilai KKM yaitu 70. Nilai tertinggi 100 dan nilai terendah 20. Pada penelitian ini, peneliti memfokuskan pada aspek isu sosial berupa permasalahan kekuasaan yang ditemukan dalam puisi-puisi Taufiq Ismail. Namun, dalam uji coba pembelajaran yang telah peneliti lakukan masih terdapat hasil yang kurang bahkan jauh di bawah KKM yang telah ditentukan.

Perbedaan yang mendasar antara penelitian yang telah dilakukan oleh Basuki Priatno tersebut dengan penelitian yang penulis lakukan ini terletak pada subjek representasinya. Subjek representasi yang digagas oleh Basuki dalam puisi-puisi Taufiq Ismail adalah representasi pada kekuasaan, sedangkan subjek representasi yang peneliti analisiskan lebih spesifik kepada representasi tindakan ketidakadilan yang mengacu pada penyimpangan jenis-jenis keadilan dalam perspektif hukum. Ketidakadilan adalah isu atau permasalahan yang paling dominan dikaji dalam bidang hukum karena menyangkut hubungan antara negara dengan masyarakatnya yang tidak sedikit dapat memicu timbulnya konflik. Dengan kata lain, ketidakadilan adalah permasalahan yang tidak ada habisnya untuk dikaji karena selalu hadir dalam berbagai aspek sosial di suatu masyarakat ataupun negara. Sehingga menjadi isu menarik untuk dibahas dalam penelitian, tidak terkecuali dalam penelitian sastra yang dilatarbelakangi oleh peristiwa-peristiwa yang terjadi di masyarakat.

Kenyataan sosial yang marak terjadi sejak dahulu hingga sekarang adalah adanya sikap ketidakadilan, khususnya yang dilakukan oleh penguasa terhadap rakyatnya. Salah satunya perjuangan melawan rezim pemerintahan Orde Baru yang sering terjadi pada waktu itu sebagai bentuk protes terhadap pengekangan kebebasan hak bersuara dan berekspresi, ketidakadilan dan korupsi yang terjadi hampir di seluruh sektor aparat negara, serta kejahatan kemanusiaan yang dilakukan negara dengan aparat militernya secara sistematis. Dengan melihat fenomena-fenomena tersebut, wajarlah jika penyair melatarbelakangi teks-teks puisinya dengan kenyataan sosial sebagai bentuk kritik, perlawanan, dan kebebasan dalam berpendapat yang dibalut dengan keindahan bahasa. Oleh karena itu, peneliti akan menganalisis puisi-puisi yang merepresentasikan fenomenafenomena ketidakadilan tersebut dengan startegi literasi kritis.

Puisi-puisi yang mencerminkan pertentangan terhadap tindak ketidakadilan ditemukan pada puisi-puisi karya Wiji Thukul. Wiji Thukul merupakan sosok penyair besar Indonesia yang terkenal dengan sajak-sajaknya yang bertema tentang kerakyatan. Selain sebagai penyair, Wiji Thukul juga terlibat sebagai aktivis yang menyuarakan pendapatnya melalui karya-karya sastra. Mayoritas puisi-puisi Wiji Thukul merupakan cerminan sejarah tentang kejinya rezim pemerintahan pada waktu itu. Selain itu, tema puisi Wiji Thukul juga menyoroti masalah-masalah sosial seperti penderitaan rakyat, perjuangan, penindasan, perlawanan, dan keadilan. Tema-tema puisi ini dapat dijadikan bahan pembelajaran bagi peserta didik karena memiliki kandungan nilai-nilai sejarah, kemanusiaan, dan kebangsaan yang dapat dijadikan pedoman dalam kehidupan saat ini.

Dengan meneliti puisi-puisi Wiji Thukul yang mempresentasikan ketidakadilan diharapkan dapat ditemukan bentuk-bentuk ketidakadilan yang disorot oleh penyair dan sikap penyair terhadap masalah tersebut sehingga hasil penelitiannya dapat dijadikan alternatf pembelajaran bagi peserta didik. Temuan dalam teks puisi tersebut dikaitkan dengan realitas sosial yang sedang marak saat ini. Relevansi antara teks dengan realitas sosial dapat menjadi bahan pembelajaran bagi peserta didik. Peserta didik diharapkan dapat mengambil sikap terhadap 
penyalahgunaan keadilan itu dan memperoleh pembelajaran bahwa sikap ketidakadilan ini dapat merugikan bangsa dan negara. Dengan demikian, peserta didik diharapkan dapat berpikir kritis dan beraksi nyata terhadap keadaan bangsa saat ini. Ketika dewasa kelak, peserta didik memiliki kemampuan untuk bersikap adil dan bijaksana dalam kehidupan berbangsa dan bernegara.

Berdasarkan beberapa hal mengenai pentingnya memahami realitas sosial yang tersirat dalam puisi dan juga fakta-fakta yang telah menjadi pengamatan peneliti. Maka, peneliti menjadikan kumpulan puisi Nyanyian Akar Rumput karya Wiji Thukul sebagai bahan penelitian yang dimaksudkan untuk memberikan pemahaman bagaimana representasi ketidakadilan yang terdapat pada puisi-puisi Wiji Thukul. Adapun tujuan dari penelitian ini adalah mengkaji lebih dalam mengenai representasi ketidakadilan dalam kumpulan puisi Nyanyian Akar Rumput serta bagaimana implikasinya dalam pembelajaran apresiasi sastra pada mata pelajaran Bahasa Indonesia.

\section{METODE}

Penelitian ini menggunakan pendekatan kualitatif dengan metode analisis deskriptif. Metode kualitatif digunakan untuk memahami suatu fenomena yang berkaitan dengan latar belakang subjek penelitian secara mendalam (Moleong: 2011:7). Penelitian ini menggunakan telaah kepustakaan dari berbagai macam sumber. Sumber data pustaka berupa data primer yang berisi objek material, data-data dikumpulkan, dikelompokkan, dan dianalisis secara deskriptif.

Analisis deskriptif dilakukan dengan cara mendeksripsikan fenomena-fenomena yang ada dalam puisi dan fenomena-fenomena lain yang berhubungan dengan teks puisi. Dalam melaksanakan metode analisis deskriptif, peneliti melakukan analisis terhadap data yang dikumpulkan dan disesuaikan dengan tujuan penelitian dengan cara mengelompokkan data-data, kemudian mendeskripsikan dan menyimpulkannya.

Data dan sumber data pada penelitian ini adalah kumpulan puisi yang berjudul Nyanyian Akar Rumput karya Wiji Thukul yang di dalamnya terdapat larik-larik puisi yang mempresentasikan ketidakadilan. Terdapat 40 puisi yang menyuarakan ketidakadilan dalam kumpulan puisi Nyanyian Akar Rumput karya Wiji Thukul. Representasi ketidakadilan dalam puisi-puisi tersebut meliputi jenis ketidakadilan distributif, komutatif, kreatif, dan protektif. Namun, peneliti hanya memfokuskan pada satu jenis ketidakdilan pada penelitian ini yaitu ketidakadilan kreatif. Pemilihan tersebut didasari oleh jumlah puisi yang paling banyak ditemukan adalah puisi yang menyuarakan jenis ketidakadilan kreatif. Puisi yang merepresentasikan ketidakadilan kreatif ini ditemukan sebanyak 15 puisi.

Setelah data terkumpul secara keseluruhan, kemudian data diklasifikasikan dan dianalisis berdasarkan masalah penelitian. Dalam menganalisis data, peneliti menggunakan proses deskriptif analisis dengan tujuan untuk menguraikan pemahaman unsur intrinsik dan ekstrinsik puisi dan menemukan representasi ketidakadilan yang terkandung dalam kumpulan puisi Nyanyian Akar Rumput dengan menggunakan literasi kritis.

\section{HASIL DAN PEMBAHASAN}

Penelitian ini akan membahas mengenai representasi ketidakadilan kreatif pada kumpulan puisi Nyanyian Akar Rumput yang mana subfokus dari penelitian ini adalah (1) Representasi ketidakadilan kreatif pada puisi Peringatan dalam kumpulan puisi Nyanyian Akar Rumput; (2) Implikasi representasi ketidakadilan pada puisi dalam pembelajaran bahasa Indonesia. Pembahasan data dianalisis dengan salah satu metode apresiasi sastra yaitu Analisis Literasi Kritis pada puisi. Berikut ini adalah uraiannya mengenai hasil penelitian tersebut.

\section{A. Representasi Ketidakadilan Kreatif Pada Kumpulan Puisi Nyanyian Akar Rumput}

Penyimpangan keadilan kreatif terepresentasikan dalam kumpulan puisi Nyanyian Akar Rumput yang ditinjau dari salah satu jenis keadilan yaitu keadilan kreatif yang dikemukakan pertama kali oleh Notomihadjojo. Ia mengonsepkan bahwa yang diperlukan oleh manusia adalah "koreksi" dan/atau perhatian khusus bagi dirinya sesuai dengan kualitas, situasi serta keberadaannya sendiri. Dalam hal ini pula, orang memerlukan "equity" atau kepatutan. Sebab, kepatutan memerhatikan dan memperhitungkan situasi dan keadilan manusia individual dalam penerapan keadilan (Notohamidjojo, 1973:12). Kepatutan merupakan kebajikan yang menggerakan manusia untuk berbuat secara rasional dalam menggunakan 'apa yang adil'. Kepatutan akan menyingkirkan kekerasan dan kekejaman hukum terutama dalam situasi dan kondisi khusus.

Oleh karena itu Notohamidjojo menambahkan jenis keadilan salah satunya adalah keadilan kreatif. Keadilan kreatif (justitia creativa) adalah keadilan yang memberikan kepada setiap orang untuk bebas untuk menciptakan sesuatu sesuai dengan daya kreativitasnya (Notohamidjojo, 2011:637-638). Keadilan in memberikan masing-masing orang kebebasan dalam menciptakan kreativitas dalam berbagai bidang kehidupan, misalnya penyair diberikan kebebasan untuk menulis tanpa adanya intervensi atau tekanan apapun.

\section{a. Analisis Representasi Ketidakadilan Kreatif Pada Puisi Peringatan}

\section{Peringatan}

jika rakyat pergi
ketika penguasa pidato
kita harus hati-hati
barangkali mereka putus asa
kalau rakyat bersembunyi
dan berbisik-bisik

ketika membicarakan masalahnya sendiri penguasa harus waspada dan belajar mendengar bila rakyat berani mengeluh itu artinya sudah gawat dan bila omongan penguasa tidak boleh dibantah

kebenaran pasti terancam apabila usul ditolak tanpa ditimbang suara dibungkam kritik dilarang tanpa alasan 
dituduh subversif dan mengganggu keamanan maka hanya ada satu kata: lawan!

Solo, 86

\section{1) Pengidentifikasian Unsur Instrinsik dan Ekstrinsik Puisi}

Unsur intrinsik yang akan diidentifikasi dari puisi yang berjudul 'peringatan' meliputi beberapa aspek antara lain judul, diksi, imaji, majas, bunyi, dan tema. Selain itu, unsur ekstrinsik yang akan ditinjau yaitu dari aspek psikologis. Berikut ini adalah pemaparan dari masing-masing aspek tersebut.

a) Judul

Puisi yang dibuat pada tahun 1986 ini berjudul Peringatan. Judul ini bermakna sebagai suatu bentuk desakan atau ancaman terhadap pihak tertentu dalam masalah ini adalah penguasa. Penyair memilih kata 'peringatan' untuk menyuarakan kondisi dan perasaan yang ia dan rakyat kecil lainnya alami kepada para penguasa. Berbagai konsekuensi, kerugian, dan paksaan yang harus mereka terima mengakibatkan timbulnya luapan emosi yang memuncak dan munculah sebuah keberanian dari rakyat untuk memperjuangkan hak-hak mereka yang tidak tepenuhi. Keberanian tersebut merupakan sebuah bentuk pemberontakan dari pembungkaman yang selama ini mereka terpaksa lakukan. Semua perasaan tersebut tergambarkan oleh penyair dalam puisi ini untuk mewakili nasib rakyat yang ingin menyuarakan penderitaannya.

b) Diksi

Pemilihan diksi pada puisi Peringatan ini menggunakan bahasa sehari-hari, tidak ada kata yang bermakna konotasi yang digunakan oleh penyair. Bahasanya lugas sehingga mudah dipahami. Interpretasi penyair terhadap objek ini dapat mudah diterka oleh pembaca. Namun, terdapat penggunaan istilah yang cukup sulit diketahui maknanya oleh pembaca awam, yaitu kata subversif. Kata tersebut memiliki makna leksikal yaitu suatu gerakan dalam usaha atau rencana ingin menjatuhkan kekuasaan dengan menggunakan cara di luar undangundang. Penyair merepresentasikan makna tersebut dengan memilih istilah subversif yang sulit dipahami oleh pembaca agar terkesan tidak terlalu frontal dalam mengungkapkan pernyataan. Kata subversif terdapat pada larik berikut ini.

suara dibungkam kritik dilarang tanpa alasan

dituduh subversif dan mengganggu keamanan

Pada larik tersebut, penyair mengungkapkan alasan ia kecewa terhadap perilaku penguasa yang merugikan rakyat. Tidak hanya larangan-larangan yang rakyat harus patuhi, tetapi beberapa dari mereka pun tidak lepas dari adanya tuduhan untuk melakukan upaya menjatuhkan kekuasaan.

c) Imaji

Pada puisi Peringatan ini terdapat imaji visual (penglihatan) yang ingmenggambarkan kekecewaan penyair terhadap sikap penguasa. Imaji visual ini terlihat pada larik berikut.
jika rakyat pergi
ketika penguasa pidato
kita harus hati-hati

Pada larik tersebut, penyair membawa pembaca untuk melihat bagaimana kondisi saat penguasa sedang berpidato di hadapan masyarakat, namun beberapa dari mereka meninggalkan tempat tersebut lantaran ketidakdukungan mereka terhadap segala apa yang penguasa sampaikan pada masyarakat. Kondisi serupa sering terjadi sehingga penyair mengungkapkan fakta-fakta tersebut menjadi sebuah perumpamaan dalam menuangkan emosinya. Peristiwa tersebut seolah tervisualisasikan agar pembaca dapat menerka gambaran kondisi rakyat saat itu. Selain imaji visual, terdapat pula imaji auditif (pendengaran) dalam puisi peringatan ini. Imaji tersebut tertuang ada pada larik berikut.

kalau rakyat bersembunyi

dan berbisik-bisik

ketika membicarakan masalahnya sendiri

penguasa harus waspada dan belajar mendengar

Larik tersebut mengantarkan pembaca untuk seolah mendengar keluh kesah yang dirasakan oleh rakyat dan memperingatkan para penguasa untuk belajar memahami penderitaan rakyat. Pada larik berbisik-bisik di atas, penyair seolah mengajak pembaca untuk mendengar dan memahami kondisi rakyat bahwa saat itu mereka gelisah atas apa yang diperintahkan peguasa sehingga mereka tidak memiliki kesempatan untuk menyuarakan keinginannya. Sedangkan pada larik penguasa harus waspada dan belajar mendengar mengibaratkan agar penguasa dapat memperhatikan dan memahami nasib dan keinginan rakyat yang seharusnya dapat berperan sebagai pengayom dan penyalur aspirasi rakyat.

d) Majas

Pada puisi Peringatan ini tidak ditemukan banyak majas atau perumpamaan karena bahasa yang digunakan penyair pada puisi ini dapat mudah dipahami dengan bahasanya yang cukup lugas. Namun, peneliti menemukan beberapa diksi yang dijadikan sebuah perumpamaan untuk memaknai suatu hal dengan hal lain. Majas atau perumpamaan yang ditemukana adalah majas metafora. Ini terlihat pada larik suara dibungkam kritik dilarang tanpa alasan. Diksi suara pada larik tersebut memiliki arti lain dari arti yang sebenarnya. Makna kata suara tersebut dimaknai sebagai opini, gagasan, pendapat, ataupun kritik yang ingin rakyat sampaikan pada para penguasa. Kata 'suara' dianalogikan sebagai makna tersebut karena arti suara sendiri yang merupakan bunyo yang dikeluarkan oleh manusia. Arti tersebut disandingkan seperti pendapat atau kritik yang disampaikan oleh masyarakat sebagai tuntutan mereka terhadap penguasa untuk dapat diterima dan direalisasikan.

e) Bunyi

Rima dalam puisi ini tidak banyak ditemukan karena bunyi akhir tiap lariknya yang tidak teratur. Penyair tidak mengindahkan penggunaan bunyi yang harmonis pada puisi ini, karena ia lebih ingin menonjolkan kekuatan emosi dalam setiap pemilihan diksinya yang sangat lugas. Hanya ada beberapa di akhir larik puisi ini yang memiliki bunyi akhir sama, sepertinya penyair memilih diksi yang memiliki bunyi akhir sama di akhir puisinya ini sebagai ungkapan emosi yang memuncak. Larik terakhir yang memiliki rima yang senada yaitu pada larik berikut. 
suara dibungkam kritik dilarang tanpa alasan

dituduh subversif dan mengganggu keamanan

maka hanya ada satu kata: lawan!

Huruf-huruf vokal (a,u,o) dengan penambahan huruf konsonan /n/, khususnya pada larik di atas menandakan suara yang berkeruh tetapi tinggi dan keras. Pemaknaan bunyi tersebut juga didasari oleh pemaknaan larik di akhir puisi ini yaitu mengungkapkan emosi penyair yang memuncak yang ingin melawan kebijakan penguasa. Keselarasan rima di tiga larik terakhir ini semakin meninggi dan diakhiri dengan kata lawan! ditambah pula adanya tanda baca seru (!) yang menandakan sebuah perintah keras. Keindahan harmoni di akhir larik tersebut sebagai penyulut untuk memberikan rasa semangat, keyakinan, dan keberanian untuk meraih keadilan.

\section{f) Tema}

Puisi yang berjudul Peringatan ini mengungkapkan tema adanya upaya penuntutan rakyat terhadap penguasa atas ketidakbebasan gerak masyarakat untuk menyuarakan pendapat, gagasan, ataupun kritikan sekaligus keluh kesah yang mereka derita untuk menegakkan sebuah keadilan. Penyair yang mewakili perasaan rakyat kecil menyuarakan emosi dengan keras pada puisi ini. Tidak hanya menggambarkan kondisi dan permasalahan pada saat itu, namun penyair ingin memanfaatkan penciptaan puisi ini sebagai motivasi pada rakyat untuk dapat bangkit dalam melawan ketidakadilan yang disebabkan kebijakankebijakan penguasa. Pada puisi inilah penyair memuncakkan emosi terdalamnya terhadap penguasa atas penderitaan yang terus menerus rakyat alami dengan cara mendeskripsikan fakta-fakta yang terjadi, seperti adanya ancaman keras bagi rakyat yang frontal mengomentari tindakan penguasa.

\section{g) Aspek Histori}

Unsur ekstrinsik yang akan diidentifikasi dari puisi yang berjudul Peringatan ini ialah aspek psikologis. Dilihat dari aspek ini, emosi Wiji Thukul tampak sangat memuncak dan kesan keberanian rakyat untuk melawan penguasa terwakili dengan penulisan larik berikut.

\section{suara dibungkam kritik dilarang tanpa alasan \\ dituduh subversif dan mengganggu keamanan maka hanya ada satu kata: lawan!}

Dari larik tersebut terlihat perasaan penyair sangat emosional. Dibalik larik tersebut terbesit adanya sifat keberanian penyair yang timbul demi memberikan api semangat kepada rakyat agar mereka tidak terus menerus terpuruk dengan keadaan. Adanya sifat peduli yang dimiliki penyair membuat ia berani menuangkan kata-kata tersebut ke dalam puisinya. Secara tersirat puisi ini merupakan motivasi yang diberikan penyair kepada rakyat sekaligus sebagai peringatan dan 'ancaman' kepada para penguasa. Puisi ini diinterpretasikan sebagai sebuah motivasi karena penyair ingin menyuguhkan suatu karya tidak hanya untuk mengungkapkan fakta-fakta namun juga memberikan dorongan semangat atas segala permasalahan yang menimpa rakyat kecil pada saat itu. Melalui pesan yang ada dalam puisi ini, penyair menginginkan agar rakyat tergugah dan bangkit untuk mengungkapkan hak-haknya yang selama ini tidak dihiraukan akibat kebijakan penguasa. Sikap penyair yang berani memberikan dorongan semangat tersebut dianggap sebuah penyulut api rakyat kecil untuk dapat melawan segala aturan yang merugikan mereka.

Selain puisi ini tersiratkan sebuah motivasi, puisi ini juga berdalih sebuah peringatan dan ancaman seperti judul puisi ini sendiri yaitu Peringatan. Keyakinan dan keberanian penyair sangat tinggi dalam puisi ini, ia tidak peduli terhadap apapun yang akan ia hadapi lantaran isi puisinya yang frontal. Ia hanya mengungkapkan apapun yang ia alami dan rasakan hanya demi membela rakyat kecil. Peringatan dan ancaman tersebut tidak serta merta diungkapkan tanpa adanya alasan dan bukti. Maka itu, dalam puisi ini pun penyair sedikit memberikan gambaran terkait fakta-fakta yang terjadi saat itu. Contohnya adalah ketika siapa saja yang berani menentang kebijakan penguasa maka ia secara tegas akan diadili. Fakta seperti itulah yang dijadikan sebuah alasan dan bukti untuk membeberkan tindakan keras penguasa sehingga menimbulkan perlawanan, khususnya perlawanan yang diungkap penyair dalam puisi ini. Perlawanan tersebut tidak akan terucap apabila penyair tidak memiliki sifat pemberani dan peduli terhadap apapun yang terjadi di sekelilingnya saat itu.

\section{2) Peninjauan Literasi Kritis}

\section{a) Hasil Analisis Puisi}

Dari unsur intrinsik dan unsur ekstrinsiknya, kita bisa melihat ide atau gagasan yang secara lantang menyuarakan jerit penderitaan dan ketidakadilan. Berdasarkan judulnya Peringatan, kita bisa menebak persoalan yang dikemukakan oleh penyair. Judul ini bermakna sebagai suatu bentuk desakan atau ancaman terhadap pihak tertentu yaitu penguasa. Penyair memilih kata 'peringatan' untuk menyuarakan keberanian dalam melawan segala tindakan yang merugikan rakyat dan mengingatkan mereka agar tidak terus menerus pasrah akan keadaan. Suara keberanian tersebut tersirat sebuah ancaman dan peringatan terhadap penguasa agar mereka dapat merasakan penderitaan rakyat dan memenuhi tuntutan hak-hak mereka yang selama ini dilarang.

Perlawanan yang tersirat dalam puisi ini tergambarkan dalam pemilihan diksi-diksinya yang lugas dan jelas. Puisi ini menggunakan bahasa yang mudah dipahami pembaca karena hampir tidak ditemukan diksi-diksi yang mengandung perumpamaan yang perlu ditinjau kembali makna konotasinya. Pemilihan diksi tersebut dimaksudkan agar 'peringatan' yang disampaikan pada puisi ini dapat langsung dicerna dan dipahami bagi pembacanya, khsususnya untuk rakyat dan penguasa pada saat itu. Luapan emosi penyair dalam puisi ini pun terpampang jelas sehingga pembaca dapat langsung merasakan apa yang penyair rasakan pada saat pembuatan puisi ini bahwa penyair dengan tegas menyampaikan kekecewaan, keberanian, dan keyakinannya dengan menggunakan bahasa yang tidak terkesan bertele-tele.

Penyampaian 'peringatan' dalam puisi ini didukung dengan penggambaran penglihatan dan pendengaran dari fakta-fakta yang disebutkan dalam beberapa lariknya. Pengungkapan fakta dan kondisi saat itu tercermin dalam imaji yang digunakan penyair yaitu imaji visual dan auditif. 
Imaji penglihatan digunakan penyair untuk mengungkapkan kejadian ketika rakyat terlihat berbondong-bondong pergi meninggalkan tempat pidato yang disampaikan penguasa yang menandakan bahwa rakyat sudah putus asa dengan segala perintah mereka yang merugikan rakyat. Hal ini dikarenakan rasa kecewa rakyat yang sampai pada saat itu penuntutan hak-haknya tidak dihiraukan. Sedangkan imaji pendengaran digunakan penyair untuk mengungkapkan kejadian ketika rakyat banyak berbisik-bisik menyuarakan keluh kesahnya atas dampak yang mereka dapatkan. Kedua peristiwa tersebut adalah fakta yang penyair temukan terkait permasalahan ini, sehingga fakta tersebut dijadikan sebuah peringatan kepada penguasa atas adanya perlawanan yang dikobarkan oleh penyair pada puisi ini.

\section{b) Representasi Ketidakadilan Kreatif}

Puisi Peringatan ini menempatkan penyair sebagai pengamat sekaligus mewakili rakyat kecil atas peristiwa yang dipaparkan dalam puisi ini. Puisi ini adalah salah satu puisi pada kumpulan puisi Nyanyian Akar Rumput yang mengungkapkan adanya ketidakbebasan rakyat dalam menyuarakan kritik untuk memperjuangkan hak-hak rakyat sebagai warga negara. Kritik ini muncul akibat adanya tindakan yang tidak memihak dan merugikan rakyat kecil. Saat itu kritik yang bersifat pemberontakan terhadap kebijakan pemerintah menjadi masalah krusial yang harus disingkirkan karena sikap penguasa yang otoriter saat itu. Permasalahan kekuasaan tersebut tercermin dalam penelitian Basukit Priatno, khususnya pada analisis puisi Takut 66, Takut 98 karya Taufiq Ismail. Puisi tersebut menunjukkan adanya kekuasaan represi dimana terjadinya intervensi penguasa terhadap rakyatnya, sehingga rakyat merasa khawatir. Diksi yang merepresentasikan kekuasaan adalah kata takut yang diulang-ulang pada tiap larik. Dan puisi tersebut diilhami dari peristiwa demonstrasi tahun 1966 dan 1988. Peristiwa tersebut disebabkan amarah rakyat yang memuncak akibat adanya tindak ketidakadilan, terutama ketidakadilan dalam menyuarakan aspirasi. Hal tersebut berdampak pada rakyat kecil ketika mereka ingin menyuarakan penderitaan yang sedang mereka alami. Mereka menuntut hak-hak yang telah dirampas ataupun kerugian yang mereka dapatkan akibat adanya kebijakan penguasa yang tidak memihaknya. Semua lapisan masyarakat harus menerima dengan lapang dada apa yang diperintahkan penguasa. Bagi siapapun yang menentang ataupun memberontak akan terancam bahkan dapat diadili sehingga rakyat terpaksa harus membungkam penderitaan karena takut akan risikonya. Peristiwa tersebut menggugah penyair untuk menginterpretasikan puisi ini sebagai bentuk perlawanan terhadap kekuasaan otoriter tersebut. Perlawanan ini semata-mata untuk mendorong gelora semangat rakyat kecil untuk dapat bangkit melawan penderitaan mereka. Penayir mengajak rakyat agar tidak terpuruk dengan keadaan dan tetap terus menyuarakan keadilan yang harus ditegakkan oleh penguasa.

Fenomena yang diungkapkan oleh penyair melalui puisi ini merepresentasikan adanya tindakan penyimpangan keadilan kreatif. Keadilan yang menjunjung tinggi kebebasan setiap orang dalam menciptakan sesuatu baik berupa karya, gagasan, maupun kritikan yang diperoleh dari daya kreativitasnya. Bukti dari adanya ketidakadilan kreatif ini sangat terlihat dari adanya rasa kekecewaan penyair kepada tindakan penguasa yang membungkam semua aspirasi rakyat dalam uaya menuntut hak-hak dan keadilans sebagai warga negara. Rasa kecewa dan prihatin yang amat sangat penyair rasakan pada akhirnya menimbulkan keberanian untuk melawan segala tindakan yang merugikan rakyat kecil. Sesuai judulnya puisi ini merupakan peringatan bagi rakyat untuk dapat menumbuhkan keberanian dalam memperjuangkan hak-haknya tanpa ada rasa takut dibayangbayangi oleh ancaman penguasa. Hal itu penyair sampaikan agar rakyat tetap bersatu melawan penyimpangan keadilan yang membuat rakyat terisolasi seakan tidak dapat hidup bebas di negaranya sendiri. Selain itu, puisi ini sekaligus menjadi sebuah peringatan dari penyair kepada penguasa bahwa rakyat tetap akan memperjuangkan hak-haknya sampai tetes darah penghabisan demi mewujudkan keadilan kreatif sebagaimana yang seharusnya ditegakkan. Melalui puisi ini, Wiji Thukul memberikan pelajaran bahwasanya suara rakyat sangatlah penting untuk diprioritaskan. Itulah hak dasar mereka sebagai warga negara untuk dapat ikut andil memberikan opini, kritik, dan usulan dalam berkehidupan demokrasi. Keluh kesah mereka seharusnya didengar sebagai salah satu upaya menyejahterakan rakyat di negeri ini.

\section{b. Implikasi Representasi Ketidakadilan Pada Puisi \\ Dalam Pembelajaran Bahasa Indonesia}

Berdasarkan indikator pembelajaran sastra dalam silabus mata pelajaran Bahasa Indonesia, peserta didik harus memiliki kemampuan untuk mengapresiasi sebuah karya sastra, khususnya puisi. Peserta didik diarahkan untuk mampu menggauli puisi dan mampu memahami unsur-unsur yang terkandung dalam puisi sehingga dapat menumbuhkan penghargaan dan kepekaan pemikiran serta perasaan terhadap suatu karya sastra. Berbagai macam tema karya sastra disuguhkan kepada peserta didik, salah satunya adalah tema yang dekat dengan kehidupan peserta didik seperti isuisu sosial yang terjadi di masyarakat. Dalam kurikulum 2013 pun, guru harus dapat menyuguhkan tema pembelajaran berdasarkan konteks kehidupan sehari-hari agar peserta didik belajar memecahkan masalah berdasarkan apa yang mereka alami. Salah satu contohnya adalah isu sosial berkaitan tentang ketidakadilan yang dialami oleh masyarakat akibat kebijakan penguasa.

Penelitian terkait representasi isu atau permasalahan sosial dalam puisi yang memiliki implikasi terhadap pembelajaran sastra salah satunya penelitian yang dilakukan oleh Basuki Priatno dengan judul tesisnya "Analisis Literasi Kritis Puisi-Puisi Taufiq Ismail dalam Kumpulan Puisi MAJOI yang Merepresentasikan Kekuasaan dan Pemanfaatannya dalam Pembelajaran Puisi di SMA". Pemilihan tema isu sosial dari kumpulan puisi Taufiq Ismail ini dapat digunakan sebagai alternatif dalam pembelajaran apresiasi puisi di SMA. Peserta didik mempelajari apresiasi puisi pada KD pengetahuan 3.16 yaitu mengidentifikasi suasana, tema, dan makna beberapa puisi dalam kumpulan puisi. Selain itu, pada KD keterampilan 4.16 peserta didik 
dapat mendemonstrasikan salah satu puisi pada kumpulan puisi dengan memerhatikan vokal dan ekspresi. Jadi, pemilihan tema puisi berupa representasi kekuasaan pada kumpulan puisi MAJOI karya Taufiq Ismail dapat digunakan guru sebagai sumber pembelajaran dalam kegiatan apresiasi puisi di sekolah.

Melihat hasil penelitian yang terdahulu, maka penelitian yang telah dilakukan ini juga memiliki implikasi dalam pembelajaran sastra khususnya pada mata pelajaran Bahasa Indonesia. Dalam penelitian ini memiliki implikasi secara teoretis dan implikasi praktis. Implikasi teoretis penelitian ini adalah mengingat di dalam kumpulan puisi Nyanyian Akar Rumput ini ditemukan larik-larik puisi yang merepresentasikan rasa ketidakadilan akibat kebijakankebijakan penguasa terhadap rakyatnya, maka guru perlu mengarahkan dan memberikan stimulus kepada siswa untuk dapat memaknai isi dan pesan yang terkandung dalam tiap puisi sebagai sumber pembelajaran apresiasi dengan menerapkan metode pembelajaran yang efektif untuk mempermudah peserta didik memahami karya sastra. Dalam merepresentasikan puisi-puisi bertemakan isu sosial seperti ini, peserta didik diajak pula memaknai puisi dari sudut pandang sejarah. Karena puisi-puisi Wiji Thukul ini merepresentasikan peristiwa-peristiwa lampau yang dapat dijadikan pembelajaran di kehidupan peserta didik dewasa ini.

Penelitian ini juga dapat digunakan sebagai langkah awal untuk meneliti lebih lanjut tentang analisis literasi kritis untuk merepresentasikan tindak ketidakadilan dalam sebuah kumpulan puisi Nyanyian Akar Rumput karya Wiji Thukul. Selain itu, setidaknya dengan penelitian ini dapat memberikan sumbangan yang berarti dan tambahan informasi bagi peneliti lain yang berminat untuk mengembangkan lebih lanjut mengenai analisis literasi kritis pada puisi yang merepresentasikan tindak ketidakadilan dalam kumpulan puisi Nyanyian Akar Rumput dan relevansi kumpulan puisi ini juga dapat dijadikan sebagai materi pembelajaran.

Implikasi praktis penelitian ini dapat digunakan dan dimanfaatkan bagi guru dan siswa sebagai materi pembelajaran apresiasi puisi. Hasil penelitian mengenai representasi ketidakadilan pada kumpulan puisi Nyanyian Akar Rumput ini dapat dijadikan bahan ajar. Penerapan penelitian ini sebagai bahan ajar berpedoman pada silabus, RPP, Buku Guru dan Buku Siswa Kurikulum 2013 dimana peneliti mengimplikasikan sumber pembelajaran berupa kumpulan puisi Nyanyian Akar Rumput karya Wiji Thukul untuk pembelajaran Bahasa Indonesia siswa kelas X dengan kompetensi dasar 3.16 yaitu mengidentifikasi suasana, tema, dan makna beberapa puisi dalam kumpulan puisi. Guru dapat menggunakan penelitian ini sebagai sumber pembelajaran dalam materi apresiasi puisi. Selain itu, pemilihan tema puisi ini dapat dijadikan bahan pembelajaran bagi peserta didik karena memiliki kandungan nilai-nilai sejarah, kemanusiaan, dan kebangsaan yang dapat dijadikan pedoman dalam kehidupan saat ini.

Bagi mahasiswa yang bergelut di bidang pengajaran maupun bidang studi kebahasaan, penelitian mengenai representasi ketidakadilan pada puisi ini merupakan bekal yang sangat penting untuk lebih menguasai studi analisis literasi kritis khususnya pada puisi. Selain itu, apabila mahasiswa mampu untuk menganalisis suatu karya sastra maka mereka juga lebih memiliki nilai apresiasi yang tinggi kepada karya sastra. Mempelajari studi analisis literasi kritis untuk mengapresiasi puisi sangat diperlukan bagai mahasiswa agar target akademik yang diinginkan dapat tercapai dengan baik. Berdasarkan uraian di atas, maka penelitian ini memiliki implikasi dalam pendidikan bahasa yang bermanfaat bagi guru, siswa, maupun mahasiswa sebagai peneliti, khususnya pada penelitian sastra.

\section{SIMPULAN}

Representasi ketidakadilan pada suatu karya sastra dengan menerapkan metode analisis literasi kritis merupakan upaya mengapresiasi secara kritis suatu karya sastra yang mengandung isu-isu sosial, dalam hal ini adalah masalah penyimpangan keadilan yang ditemukan dalam sebuah kumpulan puisi. Penyimpangan keadilan yang peneliti temukan dalam puisi tersebut yaitu penyimpangan terhadap keadilan kreatif. Berdasarkan penelitian yang telah dilakukan tentang representasi ketidakadilan dalam kumpulan puisi Nyanyian Akar Rumput karya Wiji Thukul ada beberapa hal yang diteliti dari penelitian ini, yaitu (1) Representasi ketidakadilan kreatif yang ditemukan pada kumpulan puisi Nyanyian Akar Rumput, (2) Implikasi representasi ketidakadilan pada kumpulan puisi Nyanyian Akar Rumput dalam pembelajaran bahasa Indonesia.

Berdasarkan hasil penelitian dan teori-teori yang dijadikan landasan dapat direkomendasikan bahwa melalui kumpulan puisi Nyanyian Akar Rumput karya Wiji Thukul ini ditemukan makna puisi yang merepresentasikan suatu tindakan penyimpangan sosial yaitu ketidakadilan yang tergambar dalam berbagai peristiwa yang melatarbelakangi puisi-puisi tersebut. Pendidik dan pembelajar bahasa Indonesia dapat memperoleh gambaran mengenai adanya makna puisi yang merepresentasikan sikap ketidakadilan dalam sebuah kumpulan puisi Nyanyian Akar Rumput karya Wiji Thukul. Selain itu, tidak menutup kemungkinan buku kumpulan puisi Nyanyian Akar Rumput karya Wiji Thukul ini dapat digunakan sebagai alternatif sumber belajar bagi guru dan siswa dalam pembelajaran apresiasi puisi pada mata pelajaran Bahasa Indonesia.

\section{DAFTAR PUSTAKA}

Basir, U. P. M. (2017). ASPEK “KESASTRAAN" DALAM KURIKULUM BAHASA INDONESIA: SEJUMLAH PROBLEMATIKA TERSTRUKTUR. FKIP $e$ PROCEEDING, 227-236.

Indriati, D. A., \& Haryadi, H. (2014). PENINGKATAN APRESIASI PUISI DALAM PEMBELAJARAN PUISI DENGAN MEDIA MUSIK DI SMA NEGERI 11 YOGYAKARTA. LingTera, 1(2), 156-167.

Moleong, J. (2011). Metodologi Penelitian Kualitatif. Bandung: PT Remaja Rosda Karya. 
Notohamidjojo, O. (1973). Rahasia Hukum.Jakarta: BPK Gunung Mulia.

Notohamidjojo, O. (2011). Kreativitas yang Bertanggungjawab. Salatiga: Universitas Kristen Satya Wacana.

Priyatni, E.T. (2010). Membaca Sastra Dengan Ancangan Literasi Kritis.Jakarta: Bumi Aksara.

Ratna, N.K. (2012). Teori, Metode, dan Teknik Penelitian Sastra. Yogyakarta: Pustaka Pelajar.

Sjarif, M. T. C., \& Prasetio, A. (2017). Analisis Wacana Kritis Teun A. Van Dijk Dalam Puisi "aku Masih Utuh Dan Kata-kata Belum Binasa" Karya Wiji Thukul. eProceedings of Management, 4(3).

Thukul, Wiji. (2014). Nyanyian Akar Rumput;Kumpulan Lengkap Puisi Wiji Thukul. Jakarta: PT Gramedia Pustaka Utama. 